\title{
Dexrazoxane Treatment for Intrathoracic Anthracycline Extravasation
}

\author{
Lisa Schulmeister \\ Oncology Nursing Consultant, New Orleans, LA, USA
}

Perforation of the superior vena cava (SVC) is an unusual but potentially harmful complication of central venous catheters (CVC). As noted in the article 'Perforation of the Superior Vena Cava - A Rare Complication of Central Venous Catheters' [1], if chemotherapy is administered via a CVC that has perforated the SVC or has migrated outside of the SVC, the chemotherapy will be given into the thoracic cavity instead of the venous system. If an anthracycline is given, such as daunorubicin, doxorubicin, epirubicin, or idarubicin, an intrathoracic extravasation injury (tissue necrosis) will result. The article states that 'there are promising reports of the use of dexrazoxane as an antidote in the treatment of subcutaneous anthracycline extravasation in humans' (page 264). I would like to make readers aware that dexrazoxane $\left(\right.$ Savene ${ }^{\circledR}$, TopoTarget Germany AG, Frankfurt/M., Germany) $20 \mathrm{mg} /$ $\mathrm{ml}$ powder for concentrate, which contains $500 \mathrm{mg}$ dexrazoxane (as hydrochloride) per vial and Savene Diluent for solution for infusion, received European marketing authorisation on 28/07/2006 and is supplied as an emergency treatment kit for single-patient use. Savene is indicated for the treatment of anthracycline extravasation and is a systemic treatment that is administered daily for 3 consecutive days. Full prescribing information can be found at www.savene.com.

In two prospective clinical trials conducted in four European countries, 53 of $54(98.2 \%)$ patients with biopsy-confirmed anthracycline subcutaneous extravasations treated with dexrazoxane did not develop tissue necrosis, and 38 of the patients (71\%) were able to continue scheduled chemotherapy without postponement. 1 patient $(1.8 \%)$ experienced tissue necrosis despite dexrazoxane treatment and required surgical debridement. Pain and sensory disturbances, both rated as mild, were the most common sequelae of treatment [2].

Although the article states that there are no data on the use of dexrazoxane in treating an intrathoracic anthracycline extravasation, there is a published case report that describes treatment of an intrathoracic epirubicin extravasation [3]. Approximately $140 \mathrm{mg}$ of epirubicin extravasated into the pleural space when the tip of an implanted port catheter became misplaced. A pleural drain was inserted and the pleural cavity was immediately flushed with $1000 \mathrm{ml}$ normal saline on 2 consecutive days. Dexrazoxane was also infused intravenously for the first three consecutive days. Other than transient elevation of liver enzymes, no side effects were observed. A computed tomography scan on day 13 revealed a thoracic empyema and surgical decortication of the lung was performed. A chest $\mathrm{X}$-ray done 3 months post-operatively showed minor abnormalities and the patient resumed chemotherapy. The authors concluded that dexrazoxane treatment should be considered for intrathoracic anthracycline extravasations [3]. Also in another report, dexrazoxane was successfully used to treat anthracycline extravasations [4].

There is compelling data about the safety and effectiveness of dexrazoxane in systemically treating anthracycline extravasations. The Savene emergency treatment kit is now available for clinical use and should be available in any institution where anthracycline vesicants are administered.

\section{References}

1 Jost K, Leithäuser M, Große-Thie C, Bartolomaeus A, Hilgendorf I, Andree H, Casper J, Freund M, Junghanss C: Perforation of the superior vena cava - a rare complication of central venous catheters. Onkologie 2008;31:262-264.

2 Mouridsen HT, Langer SW, Buter J, Eidtmann H, Rosti G, de Wit M, Knoblauch P, Rasmussen A, Dahlstrøm K, Jensen PB, Giaccone G: Treatment of anthracycline extravasation with Savene (dexrazoxane): results from two prospective clinical multicentre studies. Ann Oncol 2006;18:546-550.

3 Uges JW, Vollaard AM, Wilms EB, Brouwer RF: Intrapleural extravasation of epirubicin, 5-fluouracil, and cyclophosphamide treated with dexrazoxane. Int J Clin Oncol 2006;11:467-470.

4 Frost A, Gmehling D, Azemar M, Unger C, Mross K: Treatment of anthracycline extravasation with dexrazoxane - clinical experience. Onkologie 2006;29: 314-318.

\section{KARGER}

Fax +497614520714

Information@Karger.de

www.karger.com (c) 2008 S. Karger GmbH, Freiburg

Accessible online at:

www.karger.com/onk
Lisa Schulmeister, RN, MN, APRN-BC, OCN ${ }^{\circledR}$, FAAN

Oncology Nursing Consultant

282 Orchard Road

River Ridge, LA 70123, USA

LisaSchulmeister@hotmail.com 